\title{
光弾性学的方法による砂中応力の測定について
}

\begin{tabular}{|c|c|c|c|c|}
\hline 正 員 & 村 & 山 & 朔 & 郎* \\
\hline 正 員 & 丹 & 羽 & 義 & 次** \\
\hline 員 & 川 & 本 & 朓 & 万*** \\
\hline
\end{tabular}

\section{STUDIES ON THE PHOTO-ELASTIC MEASUREMENT OF STRESSES IN A SOIL MASS}

\author{
By Dr. Eng., Sakuro Murayama, C.E. Member, Dr. Eng. Yoshiji Niwa, C.E. Member \\ and Toshikazu Kawamoto, C.E. Member
}

\begin{abstract}
Synopsis: The authors studied on the applicability of photo-elastic method to the measurement of stresses in a soil mass. For this purpose, small cylindrical hollow pieces of photoelastic material (Epoxy resin) were embedded in the dry sand mass, which was loaded by a rigid plate locally placed on its surface, and their stresses were frozen, then the stresses and their distribution in the sand mass were measured by taking out the pieces and analyzing their frozen stresses photo-elastically.
\end{abstract}

As a result of the experiment above stated, it became clear that the directions of principal stress and the feature of stress distribution in the sand mass agreed well with the results calculated by Fröhlich's formula, but the measured magnitude of stress differed a little from the calculated one. But the difference in the stress magnitude can be corrected by multiplying an experimental coefficient $K$ on the measured stress.

要旨 著者等は光弹性学的方法による土中応力の測定について研究を行つた。この目的のため光弾性 材料で造られた小さい円環試験片を表面上飞載荷された土中飞埋込み, 凍結光弹性実験を用いて試験片 飞生ずる応力を解析することマより土中の応力分布を測定した。

実験の結果土中の主応力方向特よび応力分布の形状は Fröhlich 式化よる計算結果とよく一致するが, 測定応力值の大きさは計算值と相違することが明らかにされた。しかしこの応力の大きさにたいする差 異は測定值飞実験係数 $K$ を乗ずること飞よつて補正されうる。

\section{1. 緒言}

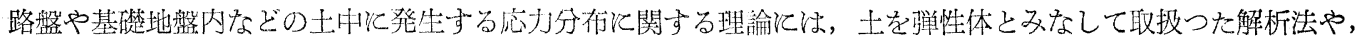
粉体の特性を考慮して弾性諭飞修正を加えた集弹性論的解法なぞがある。これら理諭の検照の目的で行われた土 中応力の測定も少なくないが，従来用いられた各種の土压計はいずれも一平面の受圧面に感じる土圧のみを計測 するもので，受圧面の法線方向の応力分值のみしか測定できない欠点があつた。この欠点を除くとともに，土中 応力の正確な主応力方向と主応力值とを同時飞測定するために，村山は土中に微小な光弾性材料の試験片を多数 埋め込み，それを応力凍結させた後取出し，各位置に埋込まれた試験片中に凍結された态力によつて土中応力 を光弾性学的に測定することを思いついたが，その詳細な笑験法ならびに解析てついては丹羽，川本が行い，そ の結果上記のような光弾性学的方法による土中応力測定法の実用上の可能性を明らか方ることができた。

本文はこの方法の一実験例として, 砂槽中に入れた乾燥砂の表面に剈性板による静的載荷を与えたときの砂中 応力を測定したもので, 光弾性試験片としてはエポキシ樹脂（Epoxy resin）よりなる外径 $6 \mathrm{~mm}$, 内径 $2.4 \mathrm{~mm}$ 長さ $6 \mathrm{~mm}$ の円環を用いた。これらの円環の凍結応力を光弾性装置によつて測定し， 2 次元括よび 3 次元荷重状 態の場合の砂中応力を求め, その結果について考察するとともに, 測定結果を Boussinesq あるいは Fröhlichの 式より算出した理論計算結果と対比した。 


\section{2. 実験方法および結果}

実験には乾燥した豊浦標準砂を用い，これを丈夫な 鉄製の砂槽によく締めて入れ，砂の表面にはジュラル ミン製の剛性載荷板を置き，これを通して荷重を加え た。荷重状態が 2 次元の場合と 3 次元の場合飞ついて
表-1

\begin{tabular}{l|c|c}
\hline & $\begin{array}{c}\text { 砂槽の幅, 高さ, 奥行 } \\
(\mathrm{cm})\end{array}$ & 载荷板の幅, 奥行 $(\mathrm{cm})$ \\
\hline 2 次元の場合 & $15.0 \times 10.5 \times 2.0$ & $5.0 \times 1.2$ \\
3 次元の場合 & $20.0 \times 20.0 \times 20.0$ & $4.0 \times 4.0$ \\
\hline
\end{tabular}

実験したが，それぞれの場合の砂槽および載荷板の大きさは表一1の通りである。な和いずれの場合子載荷板の 中心を砂槽の表面の中心と一致させた。

砂中に埋め込む光弾性材料の試験片はエポキシ樹脂を直径 $6 \mathrm{~mm}$, 長さ $6 \mathrm{~mm}$ の円柱形に鉹込み, ついでそれ 飞直径 $2.4 \mathrm{~mm}$ の孔を残留応力のないように同心に穿つたものである。砂は砂槽中に水平に薄風に入れ, 各層ご とに表面全面を招招う板で同一回数吒いて締め固めを行つた。円環試験片は軸を水平にし，かつ表面につけた目 印の直径が鉛直になるようにして図-1 (2 次元の場合), または 図-2 (3 次元の場合) の各位置と各層の締め

図-1

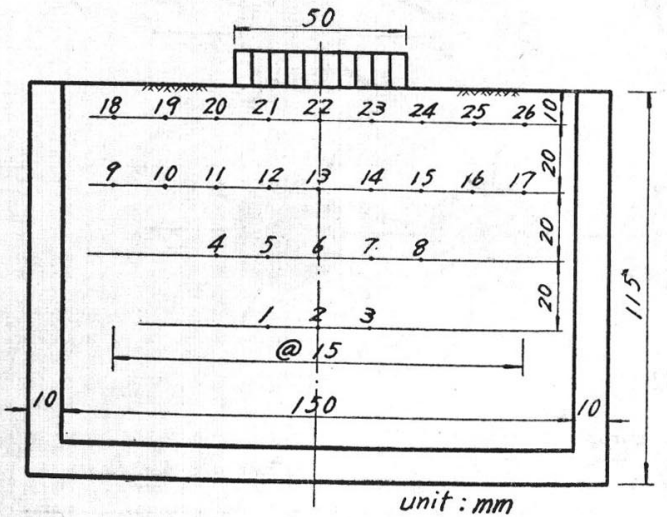

図-2

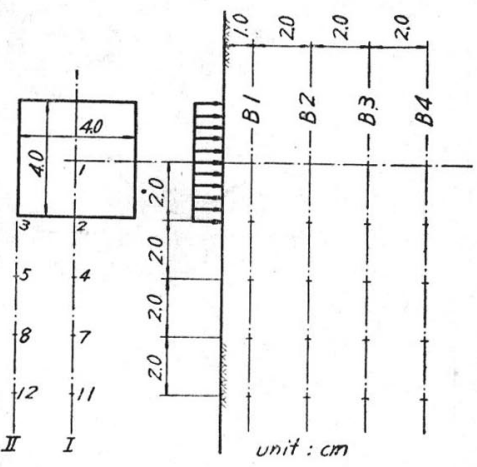

固めと同時に埋め込んだ。ついでこの砂槽を光弾性用恒温器中に入れ, 載荷板を通して載荷を与兄凍結操作を行 つて円環試験片内の応力を凍結した。その後砂を静か飞削り取り応力の凍結された試験片を取出し, 各試験片の 埋込位置と方向を照查記録した上, 浸漬法で各試験片の等色線縞写真を撮影した。この結果の一例を示すと写真 -1 は荷重強度 $w=2.76 \mathrm{~kg} / \mathrm{cm}^{2}$ (ただし $w$ は載荷々重を載荷面積で除した值)を与えた 2 次元荷重状態と拮ける 写真-1
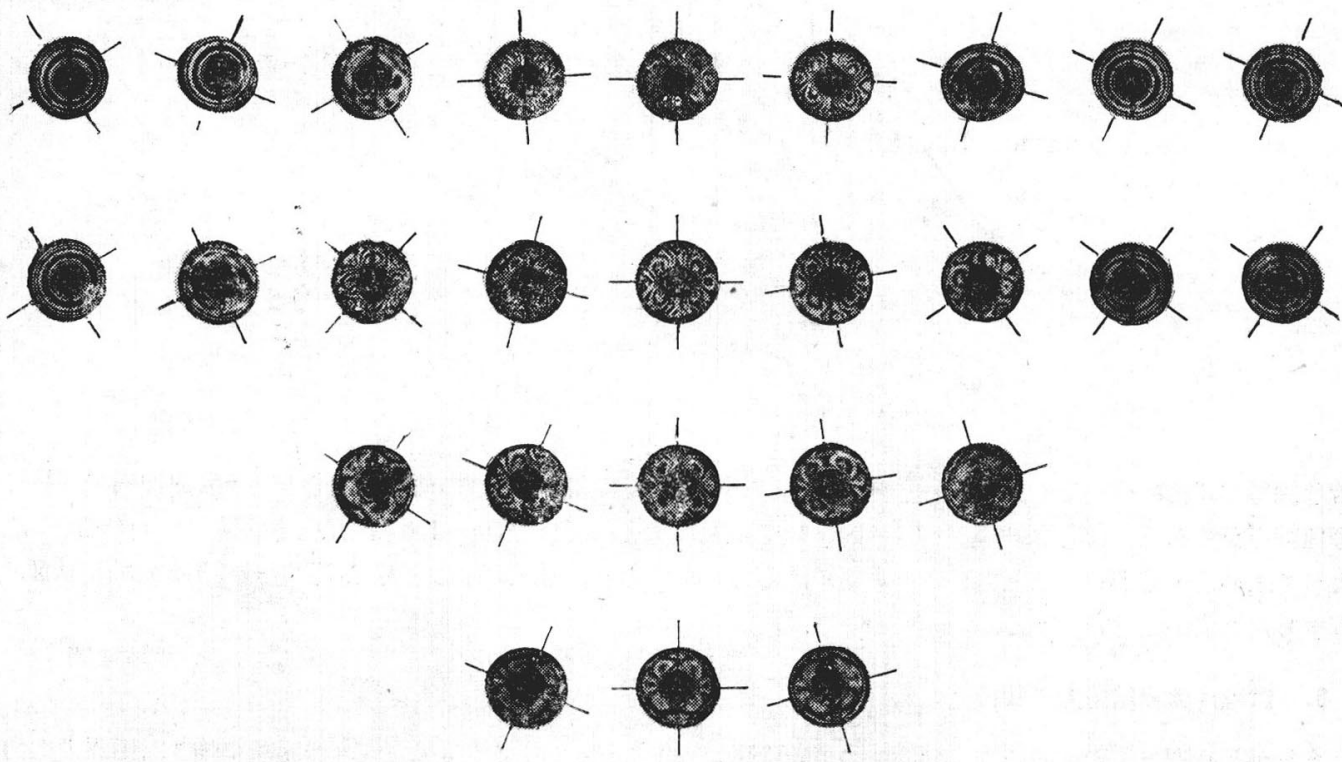


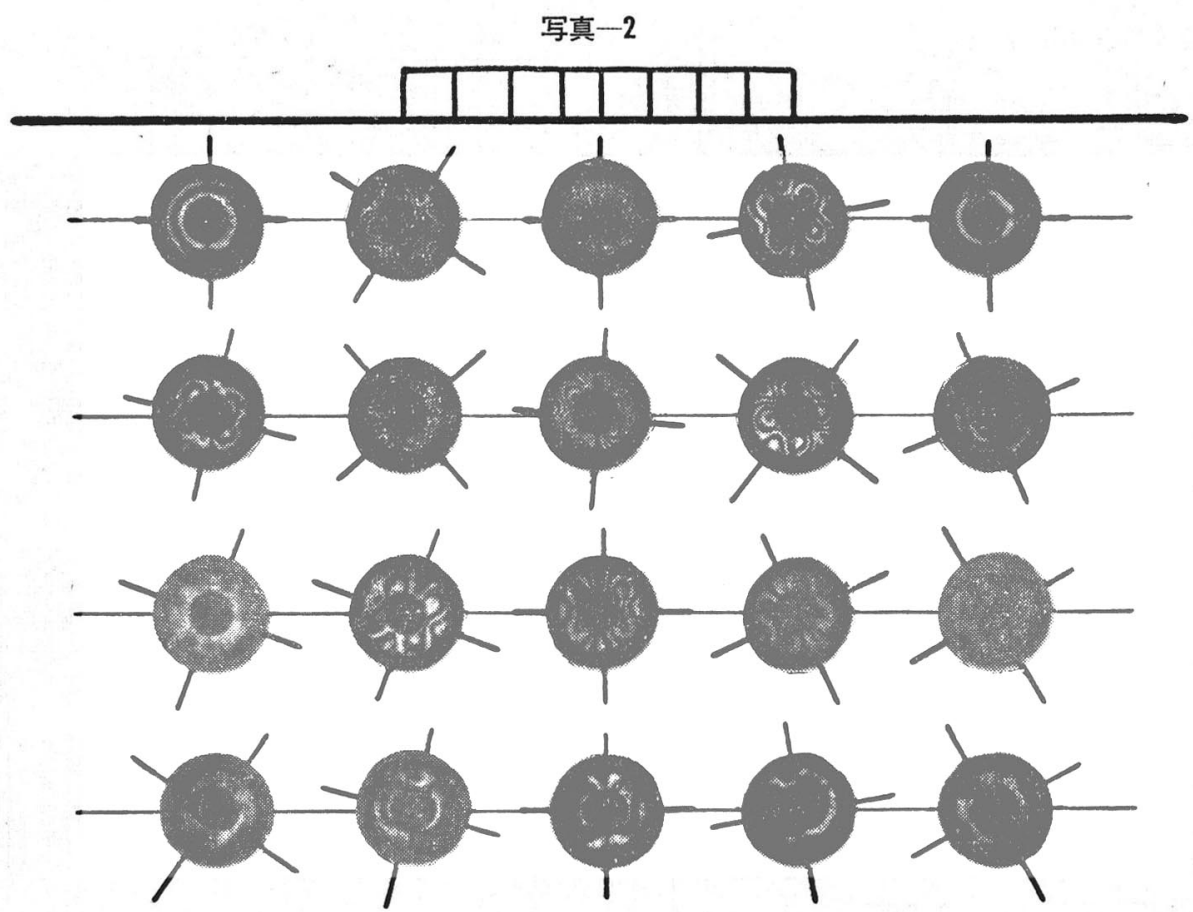

図一3

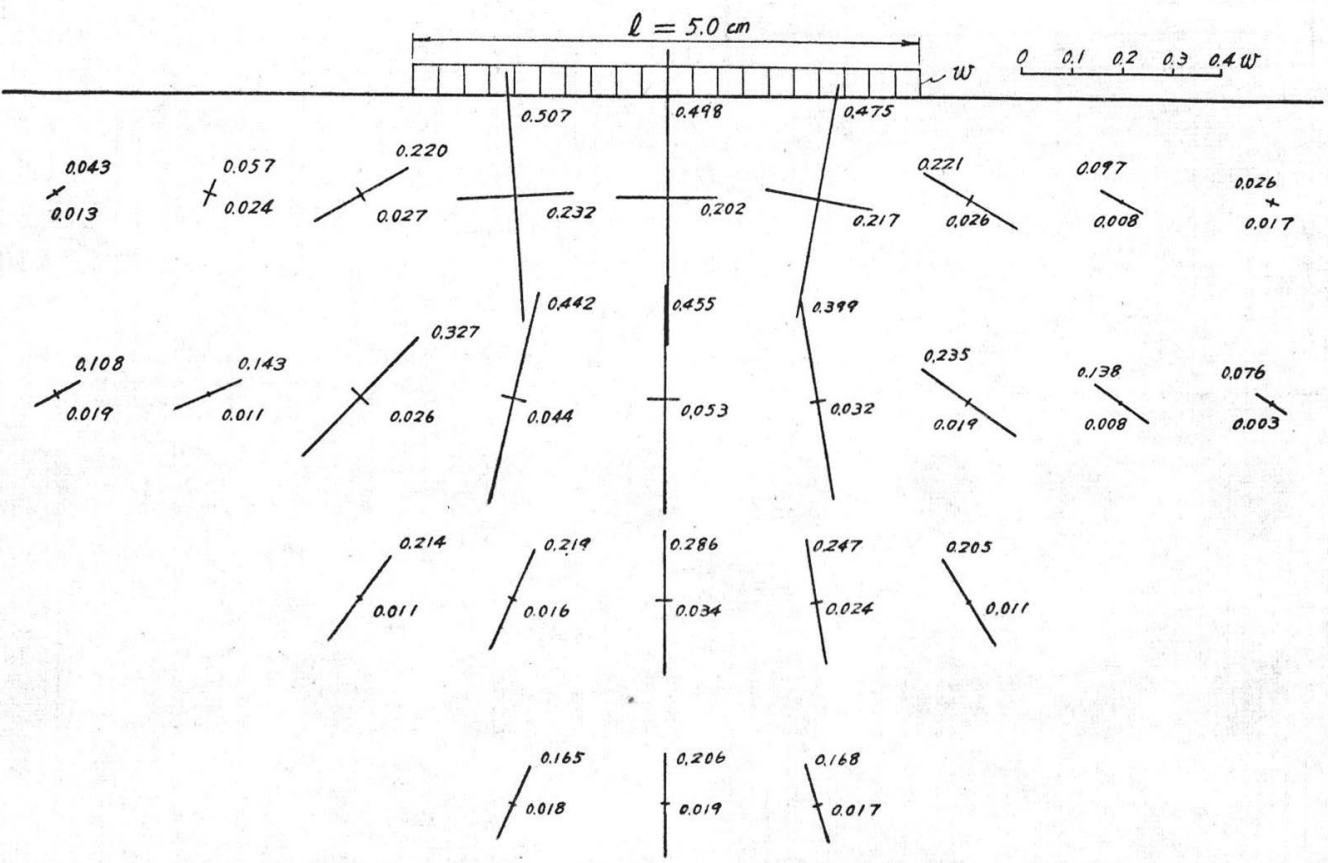

等色線写真,写真一 2 は $w=2.46 \mathrm{~kg} / \mathrm{cm}^{2}$ を与えた 3 次元荷重状態の場合の荷重面中心を通る鉛直面内の試験片の 等色線写真である。な呿 図-3 呿よび 図-4 中の実線はそれぞれ 写真一1 ( 2 次元荷重状態) より後述の方法に よつて求めた主応力の方向と大きさ括よび鉛直応力分布であり, 図一-5 中の実線は 写真一2 ( 3 次元荷重状態) よ り求めた鉛直応力分布である。

\section{3. 試験片の凍結応力の解析}

あらかじめ理論または光弾性実験によつて, 円環と作用する互に直交する二方向の作用荷重強度と円環の応力分 
図-4

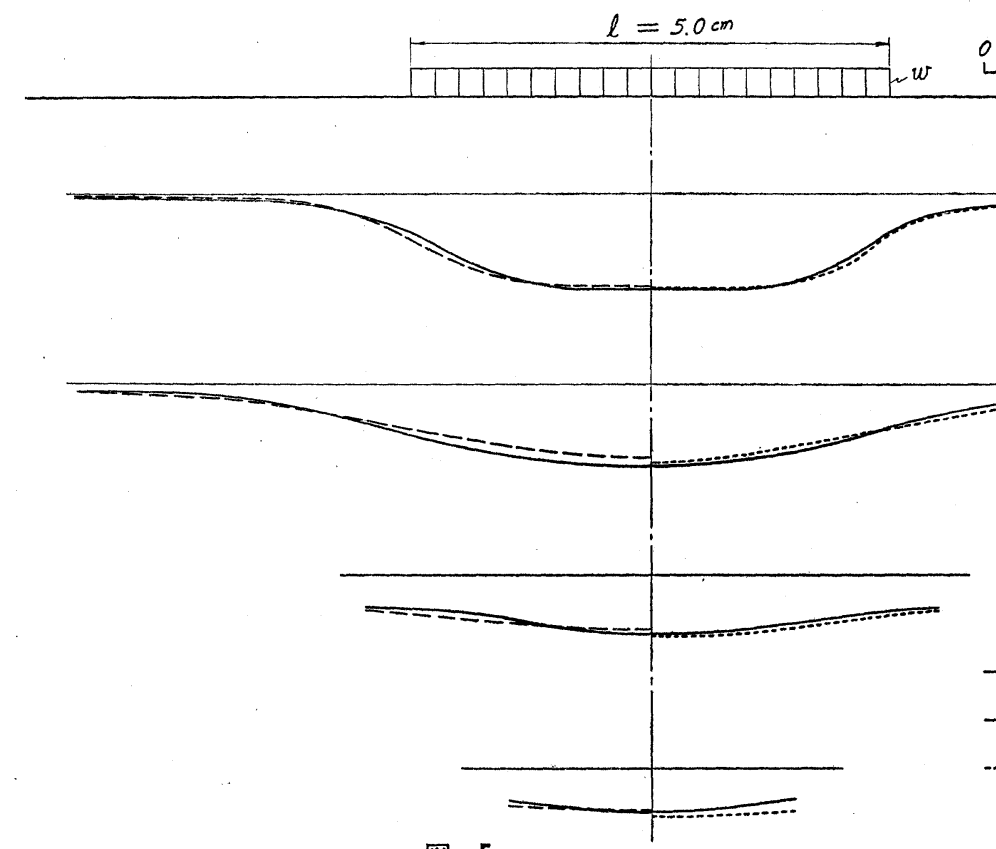

図一5
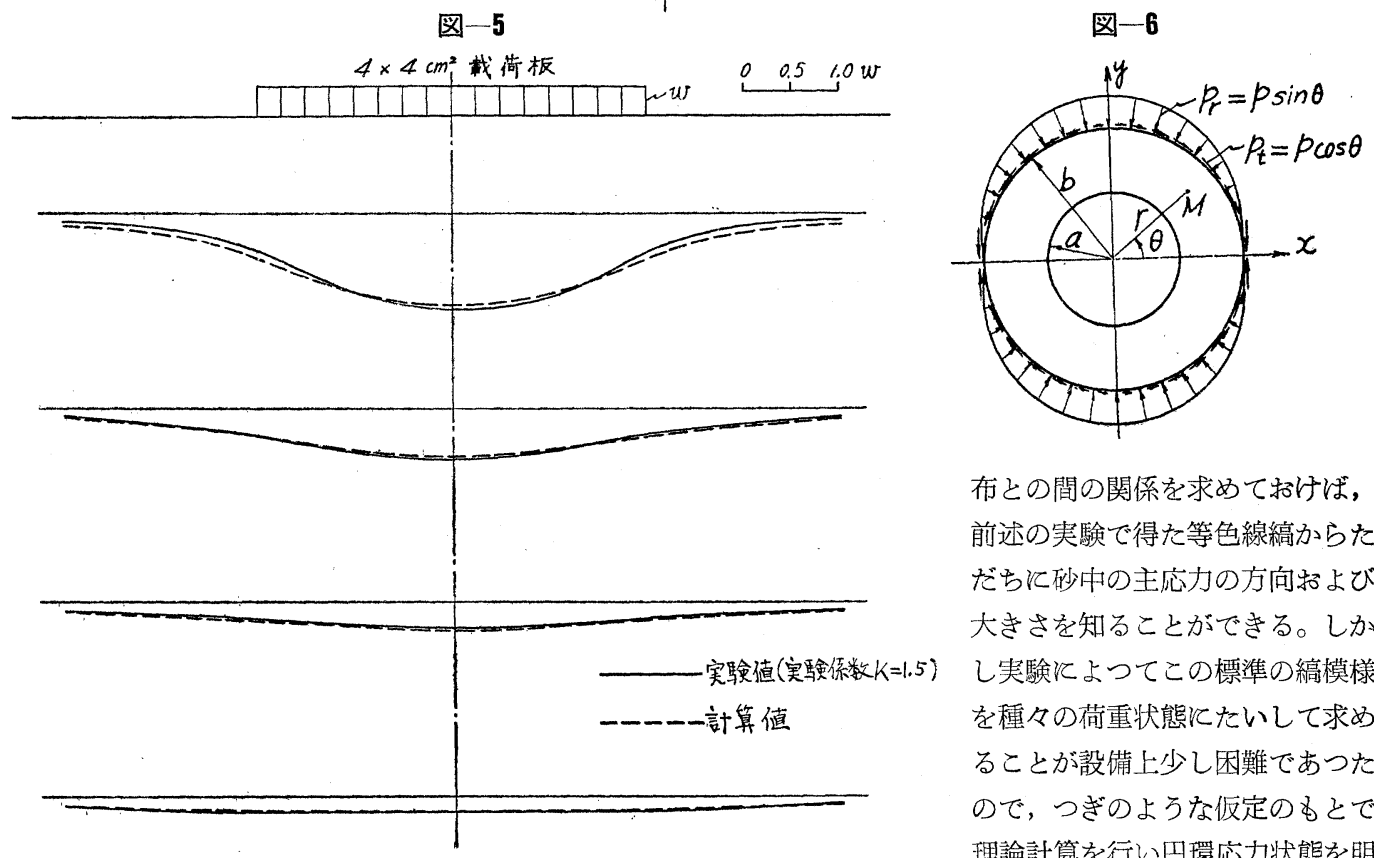

布との間の関係を求めて括けば, 前述の実験で得た等色線縞からた だち仯中の主応力の方向报よび 大きさを知ることができる。しか し実験によつてこの標準の縞模様

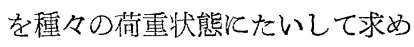
ることが設備上少し困難であつた ので，つぎのような仮定のもとで 理論計算を行い円環応力状態を明

らかにして，実験結果の整理を行うことにした。

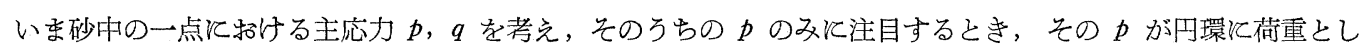
て作用する場合には 図一6 のような分布をして円環の外周作用するものと仮定する。いま円環内の応力状態を あらわす Airy の応力関数を $F$ とすれば, 各応力成分は周知のように,

$$
\sigma_{r}=\frac{1}{r} \frac{\partial F}{\partial r}+\frac{1}{r^{2}} \frac{\partial^{2} F}{\partial \theta^{2}}, \sigma_{\theta}=\frac{\partial^{2} F}{\partial r^{2}}, \tau_{r \theta}=-\frac{\partial}{\partial r}\left(\frac{1}{r} \frac{\partial F}{\partial \theta}\right)
$$

となり, この場合に適する関数 $F$ は

$$
\begin{aligned}
F & =a_{0} \log r+b_{0} r^{2}+a_{0}{ }^{\prime} \theta+\left(b_{1} r^{3}+a_{1}{ }^{\prime} r^{-1}\right) \cos \theta \\
& +\sum_{n=2}^{\infty}\left(a_{n} r^{n}+b_{n} r^{n+2}+a_{n}{ }^{\prime} r^{-n}+b_{n}{ }^{\prime} r^{-n+2}\right) \cos n \theta
\end{aligned}
$$


となる。

一方円環の外側境界上飞括ける半径方向荷重を $p_{r}(\theta)$, 接線方向荷重を $p_{t}(\theta)$ とし, 荷重状態を

$$
\begin{aligned}
0<\theta<\pi \text { rたいして, } & p_{r}(\theta)=p \sin \theta, \quad p_{t}(\theta)=p \cos \theta \\
-\pi<\theta<0 \text { とたいして, } & p_{r}(\theta)=-p \sin \theta, \quad p_{t}(\theta)=-p \cos \theta
\end{aligned}
$$

と仮定してこれを Fourier 級数で表わせば，つぎのようとなる。

$$
\begin{aligned}
& p_{r}(\theta)=\frac{2 p}{\pi}-\frac{4 p}{\pi} \underset{n=2,4,6 \ldots}{\sum} \frac{1}{\left(n^{2}-1\right)} \cos n \theta \\
& p_{t}(\theta)=\frac{4 p}{\pi} \sum_{n=2,4,6 \ldots} \frac{n}{\left(n^{2}-1\right)} \sin n \theta \ldots \ldots \ldots \ldots
\end{aligned}
$$

したがつて境界条件はこの場合つぎのようと表わされる。

$$
\begin{aligned}
& r=a \text { 扮いて, } \sigma_{r}=0, \tau_{r \theta}=0 \\
& r=b \text { K扮いて, } \sigma_{r}=-p_{r}(\theta), \tau_{r \theta}=-p_{t}(\theta)
\end{aligned}
$$

ゆえに（5）式に（1）～（4）の各式を代入して応力関数中の諸常数を求めればつぎのようになる。

$n=0$ の項, $a_{0}{ }^{\prime}=0, a_{0}=2 p / \pi\left(a^{-2}-b^{-2}\right), b_{0}=-p a^{-2} / \pi\left(a^{-2}-b^{-2}\right) \cdots$

$n=1$ の項, $a_{1}{ }^{\prime}=b_{1}=0$

$n \geqq 2$ の項,

$n$ が奇数のとき, $a_{n}=b_{n}=a_{n}{ }^{\prime}=b_{n}{ }^{\prime}=0$

$n$ が偶数のとき，

$$
\begin{aligned}
& n(n-1) a_{n} a^{n-2}+(n-2)(n+1) b_{n} a^{n}+n(n+1) a_{n}{ }^{\prime} a^{-n-2}+(n+2)(n-1) b_{n}{ }^{\prime} a^{-n}=0 \\
& n(n-1) a_{n} a^{n-2}+n(n+1) b_{n} a^{n}-n(n+1) a_{n}{ }^{\prime} a^{-n-2}-n(n-1) b_{n}{ }^{\prime} a^{-n}=0 \\
& n(n-1) a_{n} b^{n-2}+(n-2)(n+1) b_{n} b^{n}+n(n+1) a_{n}{ }^{\prime} b^{-n-2}+(n+2)(n-1) b_{n}{ }^{\prime} b^{-n}=-4 p / \pi\left(n^{2}-1\right) \\
& n(n-1) a_{n} b^{n-2}+n(n+1) b_{n} b^{n}-n(n+1) a_{n}{ }^{\prime} b^{-n-2}-n(n-1) b_{n}{ }^{\prime} b^{-n}=-4 p n / \pi\left(n^{2}-1\right)
\end{aligned}
$$

\begin{tabular}{c|c|c|c|c}
\multicolumn{5}{c}{ 表一2 } \\
\hline$n$ & $a_{n}$ & $b_{n}$ & $a_{n}^{\prime}$ & $b_{n^{\prime}}$ \\
\hline 0 & $1.091 \times 10^{-2}$ & $-3.789 \times 10^{-1}$ & - & - \\
2 & $-4.684 \times 10^{-1}$ & $6.085 \times 10^{-1}$ & $-9.370 \times 10^{-5}$ & $1.313 \times 10^{-2}$ \\
4 & $1.369 \times 10^{-1}$ & -2.460 & $1.156 \times 10^{-8}$ & $-1.106 \times 10^{-6}$ \\
6 & 1.489 & $-1.900 \times 10$ & $5.176 \times 10^{-11}$ & $-4.343 \times 10^{-11}$ \\
8 & $-1.304 \times 10$ & $1.600 \times 10^{2}$ & $-1.345 \times 10^{-13}$ & $1.079 \times 10^{-11}$ \\
10 & $5.989 \times 10$ & $-5.940 \times 10^{2}$ & $1.667 \times 10^{-16}$ & $-1.334 \times 10^{-14}$ \\
\hline
\end{tabular}

したがつて（6）～（8）式より諸常数が求ま り円環内の応力をろることができる。

いま実験用いた試験片 $(a / b=0.4)$ 飞つ いて, $p=1$ として $n=0,2,4,6,8,10$ の 6 項 をとつて計算を行い，(6)，(8) 式中の諸常 数を算出すれば表一2のようになる。これら の諸常数を (2)，(1) 式代入して円環内孔

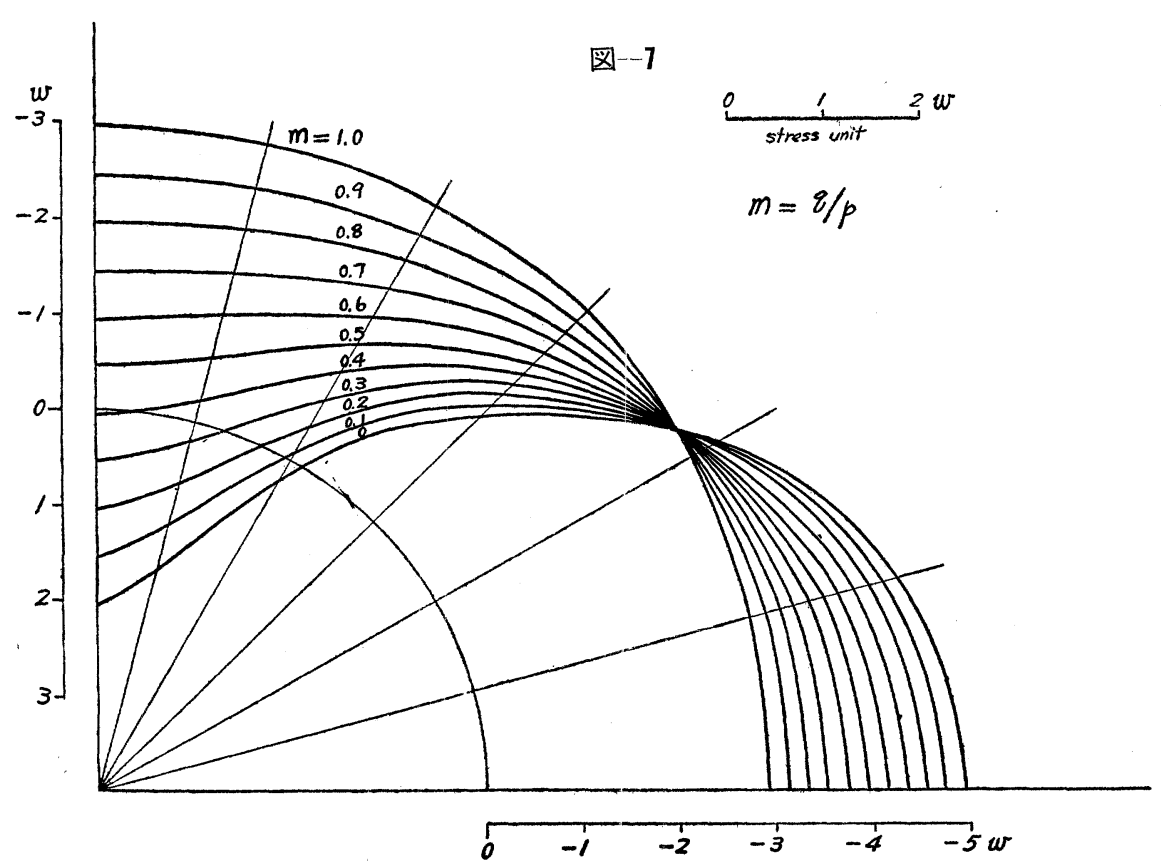


周辺 $(\boldsymbol{r}=\boldsymbol{a})$ 応力分布を求めれば 図一 7 の $m=0$ の分布曲線になる。つぎに円環内の各点に括ける主応力差 $\left(\sigma_{1}-\sigma_{2}\right)$ は次式で表わされる。

$$
\sigma_{1}-\sigma_{2}=\sqrt{\left(\sigma_{r}-\sigma_{\theta}\right)^{2}+4 \tau_{r \theta}{ }^{2}}
$$

上式中の $\sigma_{r}, \sigma_{\theta}, \tau_{r \theta} K$ 表一2 の常数を用いて各点の $\left(\sigma_{1}-\sigma_{2}\right)$ を求め, 光弾性縞を与光るところの円環内の等 主応力差線を求めると 図一8 のようとなる。実際とは砂中の荷重状態は一軸方向の $p$ のみとは限られていない

図一8 等主応力差線

(a) $p=1, q=0$

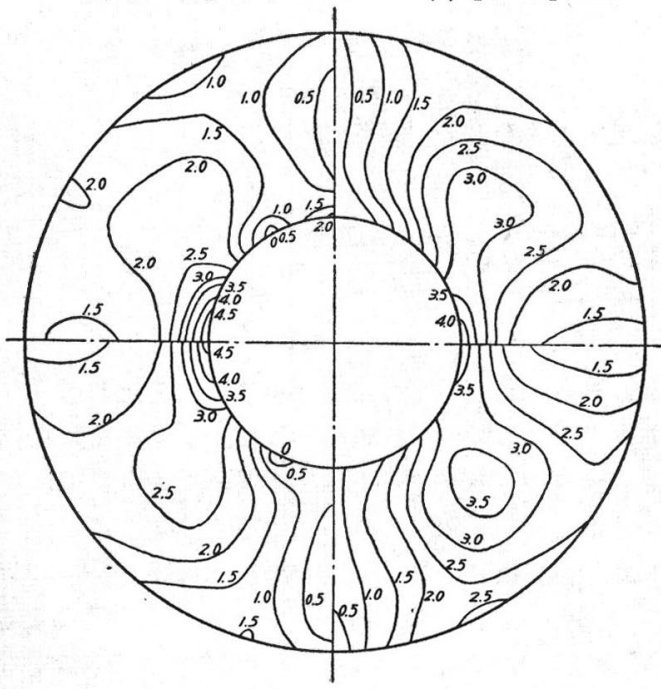

(b) $p=1, q=0.2$

(d) $p=1, q=0.6$

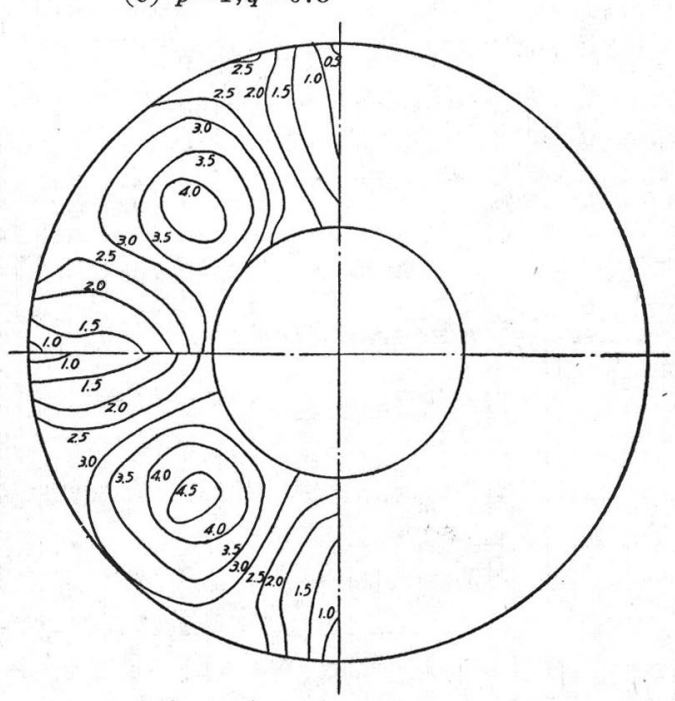

(f) $p=1, q=1$

ので, $p=1$ とこれと直角方向に $q$ が 0 1.0 の大きさで作用した場合の計算結果を重畳の原理を用いて求め

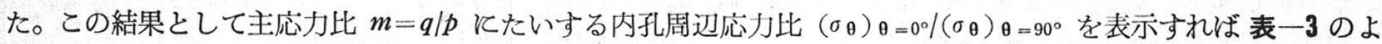
うであり，これを図示すれば 図一7 のようとなる。

表-3

\begin{tabular}{|c|c|c|c|}
\hline$\underset{q}{\text { 主応力比 }}$ & $\begin{array}{c}\text { 縞 } \\
\left(\sigma_{\theta}\right)_{\theta=0^{\circ}} /\left(\sigma_{\theta}\right)_{\theta=90^{\circ}}\end{array}$ & $(\sigma \theta) \theta=0^{\circ}$ & $(\sigma \theta) \theta=90^{\circ}$ \\
\hline 1.00 & 1.000 & $-2.938 \times w$ & $-2.938 \times v v$ \\
\hline 0.90 & 1.288 & -3.142 & -2.439 \\
\hline 0.80 & 1.724 & -3.347 & -1.941 \\
\hline 0.70 & 2.462 & -3.551 & -1.443 \\
\hline 0.60 & 3.977 & -3.756 & -0.944 \\
\hline 0.50 & 8.877 & -3.960 & -0.446 \\
\hline 0.40 & -79.790 & -4.165 & 0.052 \\
\hline 0.30 & -7.937 & -4.370 & 0.551 \\
\hline 0.20 & -4.361 & -4.574 & 1.049 \\
\hline 0.10 & -3.089 & -4.779 & 1.547 \\
\hline 0.00 & -2.436 & -4.983 & 2.046 \\
\hline
\end{tabular}

以上に円環内応力の理論的解析の概略を記 述した が，これらの計算結果を光弾性等色線縞写真の解析に 適用する順序はつぎの例と示す通りである。いま一例 として試験片 14 の等色線写真 (写真一3) とついて 説明する。まず主応力線の方向は等色線縞写真の対称
写真-3 試験片 No.14 (2 次元)

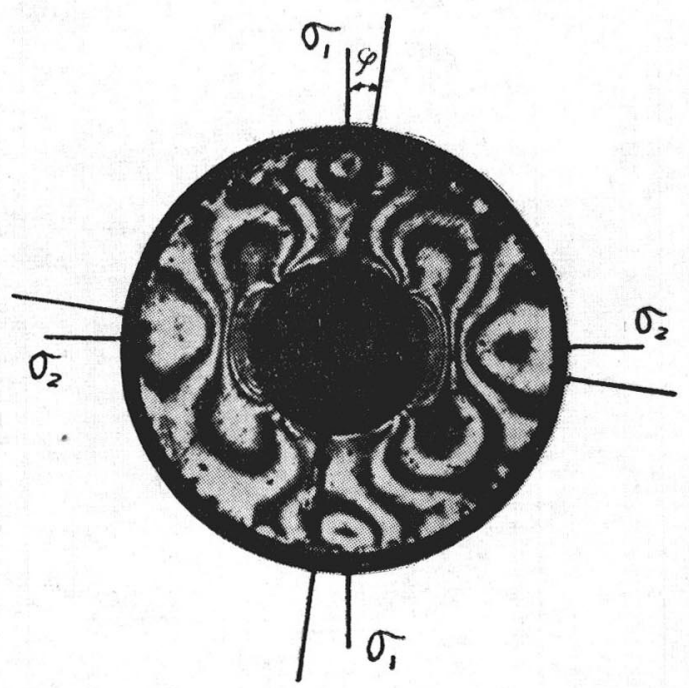

軸をるつて定め, この対称軸と鉛直線との傾きは試験片とつけた目印の直径との傾きを測定するととにより求め る。つぎに主応力の大きさの決定にはつぎの法のいずれかが用いられる。

（i）試験片の内孔周辺応力分布を等色線次数と光弾性常数から求め，乙の応力分布曲線と相似する 図一7 中 の応力分布曲線を求め, その曲線の主応力比をるつて試験片の受けた主応力比とし， $p=1$ として求めた 図一7の $\left(\sigma_{\theta}\right)_{\theta=0}$ そたいする値をるつて試験片の同一点の応力を除せば実際の主応力 $p$ が求められる。 
(ii) 各試験片の等色線縞写真より内孔円周対称軸 $\left(\theta=0^{\circ}\right.$ 呿よび $\left.90^{\circ}\right)$ 上の縞次数を読み，それら二つの值

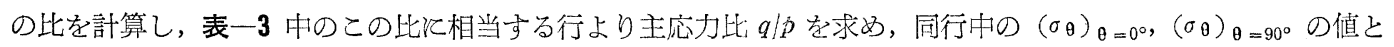
縞次数より求めた応力とより $p, q$ の值を得る。写真 -3 亿示した試験片 (pt. 14, 光弾性常数 $0.25 \mathrm{~kg} / \mathrm{cm}$, 厚

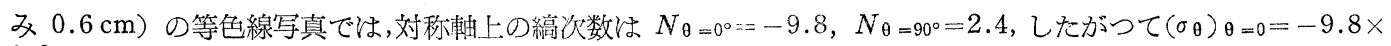
$\frac{0.25}{0.60}=-4.09 \mathrm{~kg} / \mathrm{cm}^{2}, \quad\left(\sigma_{\theta}\right)_{\theta=90}=2.4 \times 0.25 / 0.60=1.00 \mathrm{~kg} / \mathrm{cm}^{2}$, ゆ光に $\left(\sigma_{\theta}\right)_{\theta=0} /\left(\sigma_{\theta}\right)_{\theta=90}=-4.09$ であるか

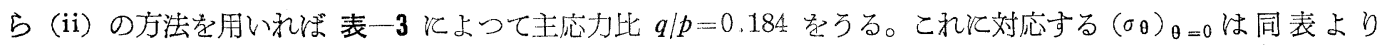
$\left(\sigma_{\theta}\right)_{\theta=0}=4.608 \times p$ となる。よつて試験時飞挌ける主応力は $p=4.09 / 4.608=0.887 \mathrm{~kg} / \mathrm{cm}^{2}, q=p \times 0.184=$

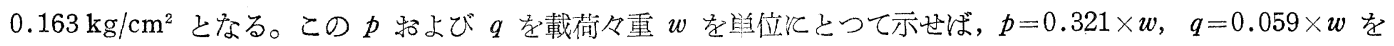

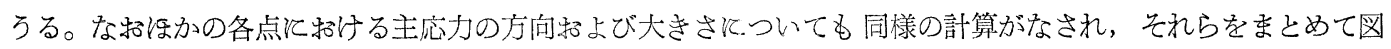

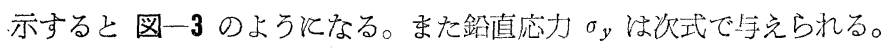

$$
\sigma_{y}=\frac{\sigma_{1}+\sigma_{2}}{2}+\frac{\sigma_{1}-\sigma_{2}}{2} \cos 2 \theta
$$

これを各点について 図一-3 より求めて図示すれば図一-4の実線となる。

\section{4. 従来の土中応力理論との比較}

従来の土中応力分布の理論としては，弾性理論飞基づいた Boussinesq 式や，とれ飞修正を加觉た Fröhlich 式

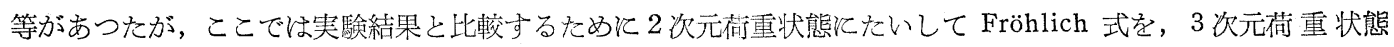
そたいして Boussinesq 式を用いて土中応力学計算した。それらの結果の一部を示せば 図-4 招よび 図一5の よろである。これらの図より考察すると，

a) 2 次元荷重状態の場合 載荷面直下付近の鉊直応力状態は各奏験ごとにかなり相違するが，深部ではほと んぞ一定している。このことは載荷面の直下では締め固め状態と全荷重, 偏心あるいは接触の不均等などとの関 係による流動, 応力集中等によるものと思われるが, ある程度以上深いとこるではこれらの影響が薄らぐためであ

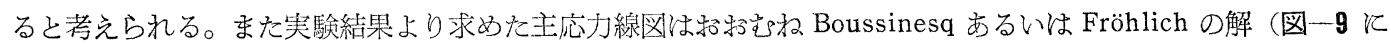
Fröhlich 式より得た主応力線図を示す) とよい一致を示しているが, 載荷面直下の主応力方向には往来みられな かつた現象が認められた。また水平断面に淠う鉛直応力の分布状態についてもかなりよい類似が認められるが， これらの值ふ Fröhlich 式による計算値よりかなり小さい。

図一9 Fröhlich 式による計算值

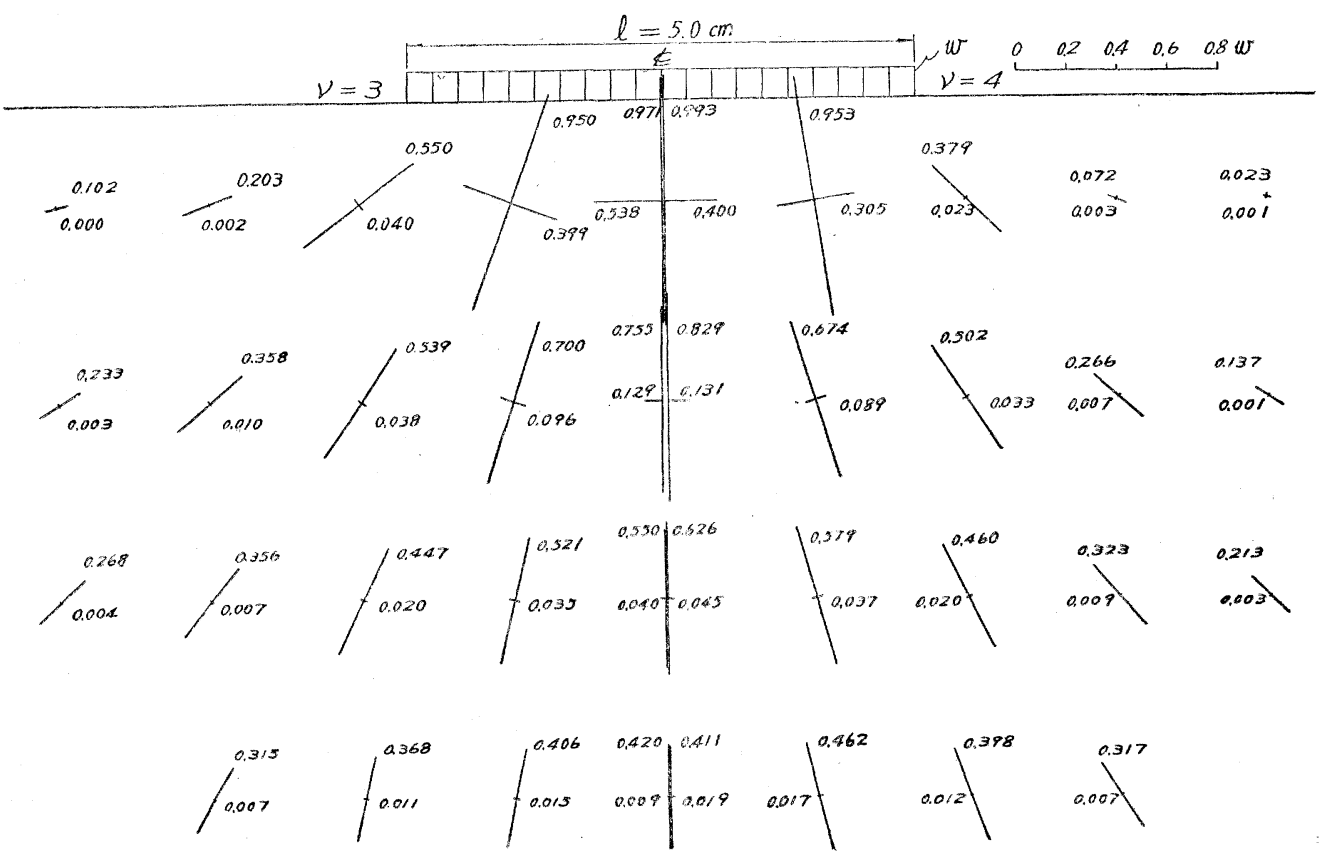


b) 3 次元荷重状態の場合 奏験を数回繰返したが, 各場合の砂の締め固め程度は載荷による載荷面の沈下量 が等しくなるようとして行つた。各実験に括ける載荷面直下近傍の応力状態の相違は 2 次元荷重状態の場合より 大きい。実験による鉊直灾力は Boussinesq の計算值とほとえど同一の分布状態をするととが判る。

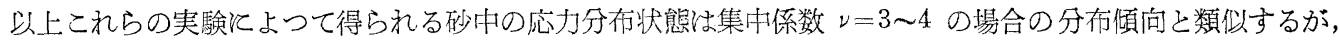
その值はいずれる理論計算值より小さい。この差異は主として 鉄製容器の内面と括ける摩擦の作用が大きい影響

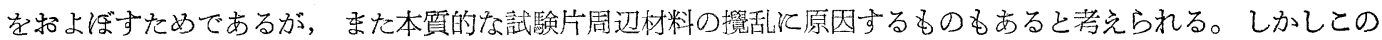

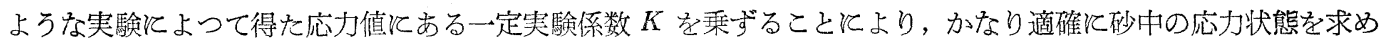
ることができる。この係数 $K$ の值はここで行つた実験て扔いては 2 次元の場合は約 2.0 であり，3 次元の場合 は 1.5 であつた。 $K$ がいかなる值をとるか惊験装置とすあわせ考完て今後研究すべき問題である。

\section{5. 結 語}

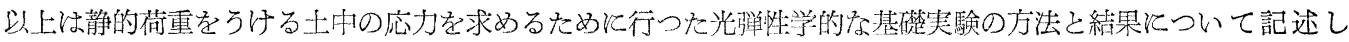
たものである。実験の結果得た土中の応力の分布状態集中係数を $\nu=3 \sim 4$ とした Fröhlich の式㳊るる理論值 とほぼ一致する。この際応力の大きさは実娩值が理諭值より全体的に小さいが，実験值飞ある一定の係数 $K$ を乗 ずることによりかなり適確に理論值と一致させることのできることが明らかになつた。この差異の原因は主とし て砂と容器内壁との摩擦等によつて生じたものと思われ，その值の決定はさらに 今後の研究にまたねばならない であろう。

以上の結果を総合して，本法は砂中の応力測定法として今後研究する洒値があると認められる。とくマ従来の 土圧計では受圧面方向の応力分值しか測定できなかつたのとたいして，本法で柱応力の大きさ招よび方向を同 時に測りえて，この種の研究に有力な資料を与光るものと思う。また液浸粉体光弾性実験では実際の秒を対象と することができない不便があるのにたいして，本法で乾燥状態の砂を実際に近い状態で実験することができ る。

本研究は国鉄の部外委託研究の一部として昭和 29 年 10 月より始め, 昭和 31 年 3 月飞国鉄へ 報告したもの であるが，との後一部研究を補足してここそ発表した。終りと研究に当り御協力いただいた絹川 治氏に謝意を 表する次第である。

(昭. 33. 9. 29)

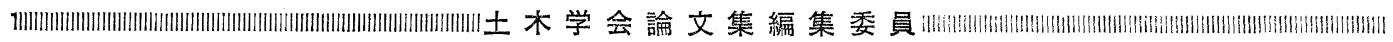

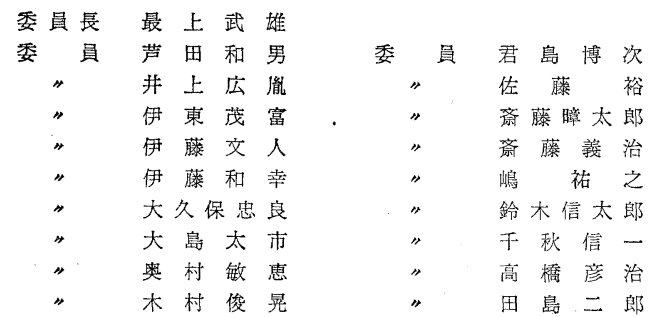

\begin{tabular}{|c|c|}
\hline 員 & 竹 内 俊 \\
\hline$"$ & 竹 下 春 \\
\hline " & 原 口 好 \\
\hline " & 比留間 \\
\hline " & 平嶋 政 \\
\hline " & 藤 井 敏 \\
\hline " & 藤 波 哲 \\
\hline " & 細 井 昌 \\
\hline " & 松 崎 柣 \\
\hline
\end{tabular}

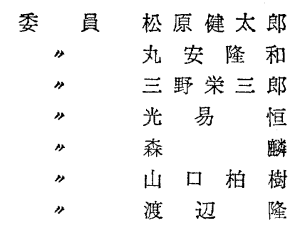

幹事德平淳

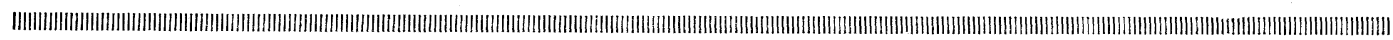

昭和 34 年 7 月 10 日 印刷

昭和 34 年 7 月 15 日 発行

\section{土木学会論文集第 63 号}

定価 120 円（宁20円）
編集者東京都新宿区四谷 1 丁目
八十島義之助
四刷所
東京都港区赤坂溜池 5 番地
株式会社 技 報 堂

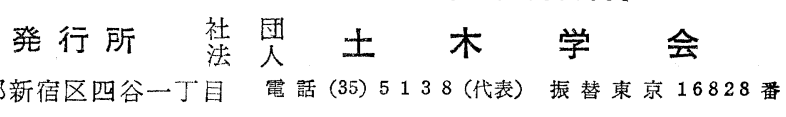

